Geothermal

biz.com

\title{
Final Technical Report
}

\author{
DE-FG36-01SF22365 \\ “Geothermal Outreach and Project Financing”
}

Bob Lawrence \& Associates, Inc.

Principal Director: Elizabeth Battocletti

345 S. Patrick Street

Alexandria, VA 22314

(703) 836-3654 / Fax: (703) 836-6086

www.bl-a.com 


\section{Final Technical Report}

\section{DE-FG36-01SF22365 \\ “Geothermal Outreach and Project Financing”}

Bob Lawrence \& Associates, Inc. Principal Director: Elizabeth Battocletti

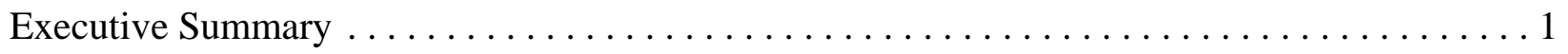

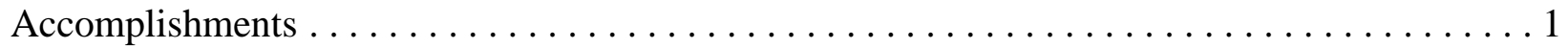

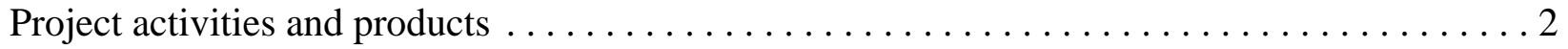

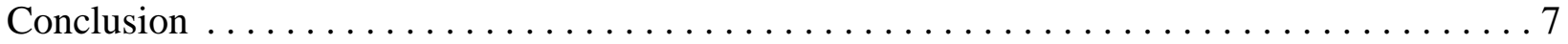

\section{Executive Summary}

The "Geothermal Outreach and Project Financing" project undertaken by Bob Lawrence \& Associates, Inc. (BL\&A) under Award Number DE-FG36-01SF22365, substantially added to the understanding of geothermal resources, technology, and small business development by both the general public as well as those in the geothermal community. The project accomplished its goals of:

1. Reducing the information barrier by increasing the understanding and awareness of geothermal energy in the 19 states of GeoPowering the West (GPW),

2. Reducing the market barrier of access to financing to increased geothermal energy use, and

3. Enabling geothermal entrepreneurs and smaller developers to more easily write business and financing plans and obtain financing.

\section{Accomplishments}

The project's core purpose was to establish geothermal energy as an economically competitive contributor to the nation's energy supply by providing outreach to local and state stakeholders, suppliers, users, and environmental groups; and delivering project financing education to potential developers, entrepreneurs, and small businesses. BL\&A met these objectives through the successful and timely completion of a wide range of project activities. The project's accomplishments result from project activities and the resulting products created and distributed. 


\section{Project activities and products}

The project included five key activities:

1. Creating and maintaining the GPW Contact Database,

2. Creating and maintaining the Geothermal-biz.com website,

3. Creating and disseminating ten (10) Geothermal-biz.com electronic newsletters,

4. $\quad$ Holding eight (8) GPW webcasts, and

5. Writing and distributing the Geothermal Small Business Workbook and Geothermal Money Book.

\section{GPW Contact Database}

The GPW contact database was created to facilitate participation by constituents and other key stakeholder groups in national and regional forums designed to foster responsible development of geothermal energy in the U.S. and removal of market barriers. It started in 2000 as an inhouse product of BL\&A, based on the almost 300 communities located within a five mile-radius of the known, yet undeveloped, geothermal resources identified by GPW. BL\&A provided this proprietary database under contract to DOE, and since October 2001, has maintained and grown it.

$$
\begin{gathered}
\text { BL\&A has grown the } \\
\text { GPW contact database } \\
600 \% \text { over the past four years. }
\end{gathered}
$$

BL\&A has worked to grow the database in several ways. It adds participants from geothermal state working meetings, the Geothermal Resources Council Annual Meeting, and other geothermal events. BL\&A designed an online sign-up form through which visitors to the Geothermal-biz.com website can request to be notified when the newsletter is published. The online form has proven to be very popular; requests are received weekly.

Privacy is an important issue to BL\&A. Individuals are always given the option to opt-out of the GPW contact database at anytime, and not receive further correspondence from BL\&A. BL\&A does not share personal information without the owner's consent.

The GPW contact database is a highly dynamic product, constantly kept up-to-date and current. It currently contains data for 2,194 people in the U.S. and around the world. Under BL\&A's management, it has grown 600 percent over the past four years, an annual increase of 150 percent, well in excess of the 25 percent annual growth forecasted in BL\&A's initial proposal.

The GPW contact database is primarily used to distribute the Geothermal-biz.com newsletter. It has been sent in text delimited and Excel form to GPW state working groups and partner organizations upon request, and is a deliverable under BL\&A's current subcontract with the National Renewable Energy Laboratory. 


\section{Geothermal-biz.com website}

Launched in early 2002, the Geothermal-biz.com website (www.Geothermal-biz.com) provides development information to the geothermal entrepreneur. It helps companies, small businesses, Native American tribes, homeowners, and individuals develop geothermal direct use and small power generation projects.

The website provides access to a wide range of information including general background on geothermal technology, specific information on geothermal resources and development in the 19 GPW states, relevant state legislation and government agencies, a calendar of events, bimonthly newsletter, solicitations, and financing and project development information.

To be more user-friendly and easy to navigate, the Geothermal-biz.com website underwent a major facelift in March 2004. Several new pages were added:

- Calendar of Events
- Current Solicitations
Financing Information
Why Geothermal?
- Why Geothermal for environmental groups?
- Why Geothermal for electric utilities?
- 2004 GeoPowering the West Annual State Working Group Summit

The Geothermal-biz.com website received 1.5 million hits from June 2004 through March 2006.

Geothermal-biz.com maintains a calendar of events for the GPW program, and is referred to by DOE's Geothermal Technology Program website. The "Calendar of Events” webpage lists U.S. and to a lessor degree international, geothermal events, including GPW and geothermal state working group meetings.

The "Current Solicitations" webpage lists solicitations and requests for proposals (RFPs) of potential interest to geothermal developers and entrepreneurs. RFPs from DOE, the U.S. Department of Agriculture, and other federal agencies; utilities; state and local governments; multilateral development banks; and other countries are posted here. 
The "Why Geothermal?" overview webpage lists the benefits of geothermal energy as well as data on the 19 GPW states' estimated direct use and power generation geothermal potential. The three targeted "Why Geothermal?” webpages provide information on geothermal energy's social, economic, and environmental benefits, drawing on work done by the Geothermal Education Office, the Geothermal Energy Association, and the U.S. Geological Survey.

In the"What's New" section of the website homepage, visitors can see at a glance what has been added to the website and when. BL\&A also posts "public service announcements” from GPW partner organizations and others on the homepage.

The Geothermal-biz.com website has become a very popular source of information, receiving over 1.5 million hits from June 2004 through March 2006.

\section{Geothermal-biz.com newsletter}

The bimonthly Geothermal-biz.com newsletter is published for the geothermal community and geothermal entrepreneurs in the U.S. and around the world. It has become known as a concise summary of what is going on in U.S. geothermal. From April

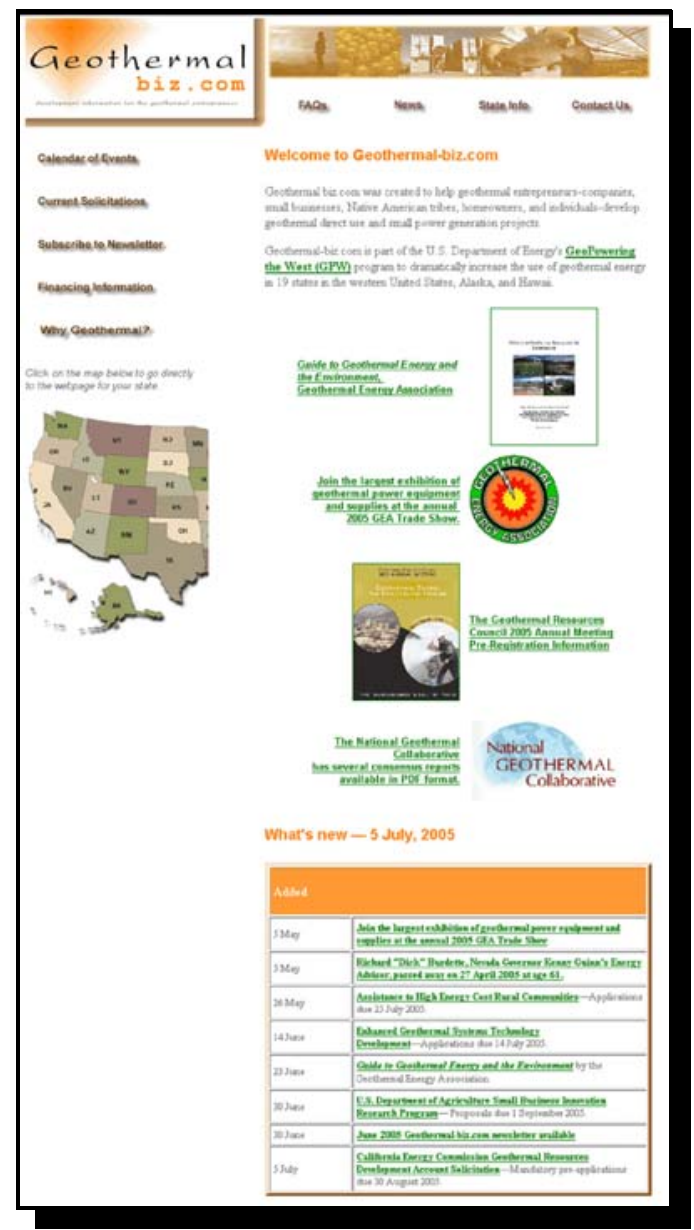

Geothermal-biz.com website 2002 to April 2004, 10 newsletters were written and notice emailed or faxed to the GPW contact database. All issues are posted on the Geothermal-biz.com website. Newsletters include national news which may be of interest to the geothermal community and geothermal entrepreneurs; a calendar of events of interest in the 19 GPW states and across the U.S.A.; a summary of what is going on in the region as a whole and the 19 GPW states; and money available from state and federal governments and private sources.

In this age of information overload, the Geothermal-biz.com newsletter is designed to be a quick read. Links are provided should readers desire additional information on a particular story.

Stories for the newsletter are collected from a wide variety of sources including federal agencies, e.g., DOE, the Department of Agriculture, the Environmental Protection Agency, the Small Business Administration, the Western Area Power Administration; other newsletters and news sources, e.g., E\&E Publishing, "RE Weekly News," "ELPC News," "Refocus Weekly,” "News.bytes (a publication of the Bureau of Land Management in California), "The Montana Green Power E-Newsletter," "Energy Newsbriefs," and the "Harvesting Clean Energy eNews Bulletin.” 
News is also sought from over 80 key contacts in the U.S. geothermal community, including DOE, GPW partner organizations and state working group leads.

\section{"I have once again found the Geothermal-biz newsletter very helpful, well put together, and fun to read.}

Notice that the newsletter is available is sent to the GPW contact database. The newsletter is also posted on the Geothermal-biz.com’s “News” webpage.

Lead stories from the April and June 2005 newsletters were:

- $\quad$ Federal Update,

- $\quad$ Susan Norwood bids farewell to GeoPowering the West,

- $\quad \$ 11.4$ million in renewable energy grants available from USDA,

- $\quad$ Save the date - 2005 GeoPowering the West State Summit,

- In Memory of Richard “Dick” Burdette,

- DOE issues Enhanced Geothermal Systems solicitation, and

- $\quad$ WGA Geothermal Task Force seeks cogent, cost-effective recommendations.

Comments received on the publication have been overwhelmingly positive:

- "The publication is terrific."

- $\quad$ "I really enjoy and look forward to the newsletter. It is a very valuable overview of the industry activity."

- "Keep up the excellent work on letting us know about many of the happenings in the geothermal community."

- $\quad$ "I have once again found the Geothermal-biz newsletter very helpful, well put together, and fun to read. You do a great job of adding just enough text to keep it informative and quickly readable. Thanks for putting so much of your energy into keeping the geothermal community knowledgeable.”

- "Thanks for the newsletter. Great stuff."

- $\quad$ "I've not received any emails since this one, and haven't requested to be dropped... could you put me back onto your email list? Thanks!”

To subscribe to the Geothermal-biz.com newsletter, go to http://www.geothermal-biz.com/news.htm\# subscribe. 
GPW webcasts

From November 2001 to March 2004, BL\&A facilitated and held eight webcasts. Subjects included:

1. $\quad$ Website design (20 November 2001)

2. $\quad$ GPW Program (4 March 2002)

3. Status of geothermal in the Senate and House Energy Bills (30 July 2002)

4. National Geothermal Collaborative webcast hosted by RESOLVE (15 August 2002)

5. $\quad$ Update on the Energy Bill and Appropriations (5 February 2003)

6. GPW webcast hosted by Western Area Power Administration (24 June 2003)

7. "Geothermal 101 Webcast” co-hosted by Western Area Power Administration, Arizona Geothermal Working Group, Center for Resource Solutions, and GeothermEx, Inc. (12 November 2003).

8. “Geothermal Direct Use 101 Webcast” hosted by Geo-Heat Center (11 March 2004)

Prior to each webcast, an email was sent to all GPW partners to get their ideas for topics that would support their work and the program as a whole. GPW partners hosted five of the eight webcasts.

Geothermal Small Business Workbook and Geothermal Money Book

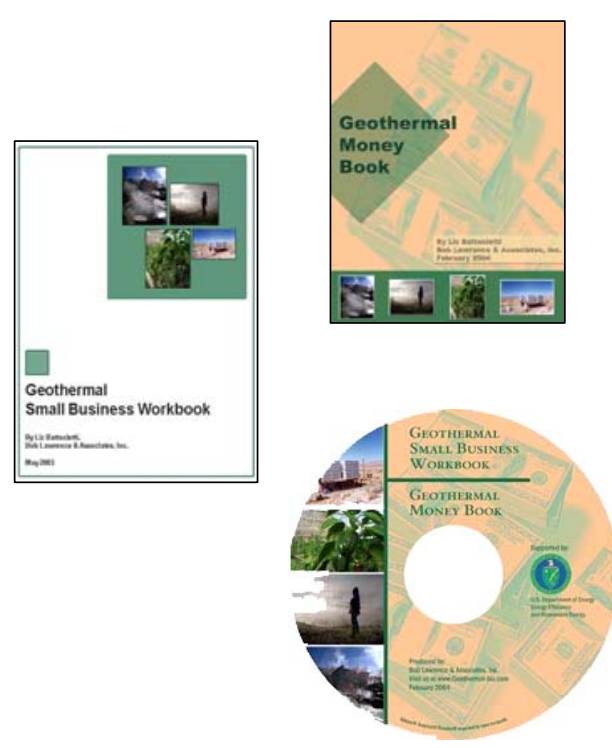

BL\&A wrote and distributed two books - the Geothermal Small Business Workbook and the Geothermal Money Book -in 2003 and 2004. The books are aimed at the small business owner or entrepreneur who has a great concept to develop a geothermal resource for direct use or small-scale power generation, but is unfamiliar with geothermal technology, writing a business and financing plan, and applying for financing. Both books are posted on the Geothermal-biz.com website and are also available on CD-ROM. To date, BL\&A has distributed about 400 free CD-ROMs.

To download the workbooks, or request a free CD-ROM, go to http://www.geothermal-biz.com/GSBW.htm.

Geothermal small business workbooks and free CD-ROM 


\section{Conclusion}

The "Geothermal Outreach and Project Financing” project has, and continues to have, significant impact. BL\&A has grown the GPW contact database 600 percent in four years. The unique Geothermal-biz.com website is the only website which contains geothermal-specific information for the 19 GPW states, and serves as a central location of information important to the geothermal community and the general public. The Geothermal-biz.com newsletter is a succinct source of what is going on with geothermal development in the United States. The Geothermal Small Business Workbook and the Geothermal Money Book have been widely distributed. BL\&A continues to support the development of the country's extensive low- and hightemperature resources. 